\title{
Filtering capacity of seagrass meadows and other habitats of Cockburn Sound, Western Australia
}

\author{
J. W. T. J. Lemmens ${ }^{1, *}$, G. Clapin ${ }^{1,2}$, P. Lavery ${ }^{2}$, J. Cary ${ }^{3, * *}$ \\ ${ }^{1}$ CSIRO Marine Laboratories, PO Box 20, North Beach, Western Australia 6020, Australia \\ ${ }^{2}$ Dept Environmental Management, Edith Cowan University, Joondalup, Western Australia 6027, Australia \\ ${ }^{3}$ Dept Environmental Protection, Marine Impacts, Perth, Western Australia 6000, Australia
}

\begin{abstract}
Macro-suspension-feeders (predominantly ascidians, sponges, bivalves) and epifaunal suspension-feeders (hydroids, spirorbids, bryozoans, barnacles, amphipods) in Posidonia meadows of Cockburn Sound, Western Australia, demonstrate a clear spatial distribution. Although this may be due to a number of environmental variables, this compares well with spatial patterns in phytoplankton levels, which are relatively high in Cockburn Sound $\left(0.94\right.$ to $\left.2.66 \mathrm{~g}_{\text {chlorophyll }} \mathrm{I}^{-1}\right)$ and are generally highest at the southeastern boundary. Macro-suspension-feeder biomass was high in Posidonia meadows (28.6 to $41.3 \mathrm{~g} \mathrm{AFDW} \mathrm{m}^{-2}$ at the southeastern boundary, 9.6 to $15.4 \mathrm{~g} \mathrm{AFDW} \mathrm{m}^{-2}$ at other sites) and generally lower in bare sediment $\left(0.2\right.$ to $\left.9.3 \mathrm{~g} \mathrm{AFDW} \mathrm{m}^{-2}\right)$, although on bare sediment of the Southern Flats (a site in the southwest) the introduced polychaete Sabella spallanzanii reaches considerable biomass (458.9 $\mathrm{g} \mathrm{AFDW} \mathrm{m}^{-2}$ ). Heterozostera $\left(1.2 \mathrm{~g} \mathrm{AFDW} \mathrm{m}^{-2}\right.$ ) and Amphibolis meadows (2.3 $\mathrm{g}$ AFDW $\mathrm{m}^{-2}$ ) were found at only 1 site each, but appear to support a low biomass of macro-suspension-feeders. Epifaunal suspension-feeders on Posidonia leaves (hydroids, bryozoans, spirorbids, barnacles, corophiid amphjpods) reached a substantial biomass $\left(2.3 \times 10^{\mathrm{b}}\right.$ feedıng units $\mathrm{m}^{-2}$ at the southeastern site; 0.6 to $0.7 \times 10^{6}$ units $\mathrm{m}^{-2}$ at other sites; 'feeding units' refers to individual polyps, zooids, etc.). Amphibolis leaves supported similar numbers of epifaunal suspension-feeders $\left(0.7 \times 10^{6}\right.$ units $\left.\mathrm{m}^{-2}\right)$ but Heterozostera supported far lower numbers $\left(80 \times 10^{3}\right.$ units $\left.\mathrm{m}^{-2}\right)$. Initial estimates indicate that the suspensionfeeding assemblages associated with Posidonia and Amphibolis meadows in Cockburn Sound are potentially able to filter the overlying water column daily, and may partially control local densities of suspended organic matter. Filtration rates in unvegetated and Heterozostera habitats are orders of magnitude lower, so benthic invertebrate control of suspended particles in these habitats is unlikely. However, habitats dominaled by the introduced polychaete S. spallanzanii, which has colonised large areas in Cockburn Sound where seagrass meadows have disappeared, have a filtering capacity of at least the same order of magnitude as that of the seagrass meadows they have replaced.
\end{abstract}

KEY WORDS: Filtering capacity - Seagrass meadows - Posidonia sinuosa - Cockburn Sound SW Australia - Suspension-feeders - Invertebrates - Sabella spallanzanii - Chlorophyll a levels

\section{INTRODUCTION}

Suspension-feeders are a large component of coastal marine ecosystems, both in terms of biomass and numbers. The term 'suspension-feeder' refers to organisms that feed opportunistically on particles suspended in the water; 'filter-feeders' refers to organisms that gather food through filtering of the water column. These concepts

\footnotetext{
-E-mail: sjaak.lemmens@per.ml.csiro.au

- Present address: CALM-Marine Conservation Branch, Fremantle, Western Australia 6160, Australia
}

are not identical, although the groups largely overlap (e.g. Jørgensen 1966). Hydroids, for instance, are not, strictly speaking, filter-feeders, but capture individual zooplankton particles directly from the water column.

A recent survey of Port Phillip Bay, near Melbourne, Australia, estimated that suspension-feeders comprised half of the benthic macro-invertebrate biomass, and processed a volume of water equivalent to the Bay in about $16.5 \mathrm{~d}$ (Wilson et al. 1993). They were also estimated to ingest $15 \%$ of all organic matter ingested by benthic macro-invertebrates, but because they have a greater assimilation efficiency than deposit- 
feeders, may account for $42 \%$ of the total assimilation of organic material by Port Phillip Bay benthic macroinvertebrates (Wilson et al. 1993).

With such a capacity for assimilating organic material, suspension-feeders - when abundant - must have an important impact on phytoplankton communities. Cloern (1982), who showed that suspension-feeding bivalves in south San Francisco Bay (USA) filtered a volume equivalent to that of the Bay at least once daily, suggested that grazing by benthos is the primary mechanism controlling phytoplankton biomass in summer and autumn. Since the depth at which seagrasses grow is largely determined by light, and phytoplankton affect light penetration (e.g. Dennison \& Alberte 1982, Fitzpatrick \& Kirkman 1995), a relationship between the densities of phytoplankton, suspensionfeeders and seagrass is likely.

Cockburn Sound, a coastal embayment near Perth, Western Australia (see Fig. 1), has suffered greatly from the effects of eutrophication: 80 to $90 \%$ of its 4000 ha of seagrass meadows rimming the Sound is estimated to have declined (Cambridge 1979, Simpson et al. 1993). Although seagrass now occupies only $10 \%$ of the area of Cockburn Sound, its communities are considered to provide an important habitat for a range of organisms (Chittleborough 1970, Wilson et al. 1978).

High nutrient inputs to Cockburn Sound have been implicated in the loss of large areas of seagrass beds (Cambridge \& McComb 1986). Excessive growth of phytoplankton has increased light attenuation, thereby causing stress to seagrass (e.g. Cambridge \& McComb 1986), which is compounded by the excessive growth of epiphytes on the seagrass (Cambridge \& McComb 1986, Silberstein et al. 1986). As seagrass beds may be an important habitat for invertebrates, including suspension-feeders (Chittleborough 1970, Wilson et al. 1978), a decline in the beds may also mean loss of habitat and a consequent decrease of invertebrate biomass.

The aim of the present study is to quantify the suspension-feeder component of seagrass meadows in Cockburn Sound, determine spatial patterns in biomass and species composition, and relate these patterns to - largely unpublished - chlorophyll a levels in the water column. Furthermore, the filtering capacity of these communities is estimated.

\section{MATERIALS AND METHODS}

Sampling method. Five sites with both Posidonia sinuosa Cambridge et Kuo meadows and unvegetated substrate ('bare' sediment) were sampled between 5 and 8 September 1994 in shallow waters of Cockburn Sound, Western Australia ( $\left.32^{\circ} 15^{\prime} \mathrm{S}, 115^{\circ} 45^{\prime} \mathrm{E}\right)$. These sites were chosen because they are widely dispersed along the rim of the Sound (Fig 1), and because of the close proximity of Sites 1,2,4 and 5 to sample sites used by the Western Australian Department of Environmental Protection for monitoring recent chlorophyll a (chl a) levels. These largely unpublished chl a data, collected during summer (December to March) between 1990/91 and 1993/94, were used to determine the distribution of phytoplankton in Cockburn Sound, and describe the food availability to suspension-feeders within the Sound. It should, however, be noted that other particulate organic material such as resuspended organic material, including phytoplankton and other detritus, may form a large food component to suspension-feeders (e.g. Stuart et al. 1982, Seiderer \& Newell 1985, Judge et al. 1993). The present study did not attempt to determine the contribution of other suspended organic materials to the spatial distribution of suspension-feeders in Cockburn Sound. Cary \& Masini (1995) indicated that the chl a distribution in Cockburn Sound is similar in winter and summer

Chl a concentrations were determined spectrophotometrically by the trichromatic method (Jeffrey \& Humphrey 1975). Approximately weekly data for surface, middle and bottom waters were available for all sites except Site 3 (Fig, 1) for the 4 summers from $1990 / 91$ to $1993 / 94$. Mean concentrations were deter-

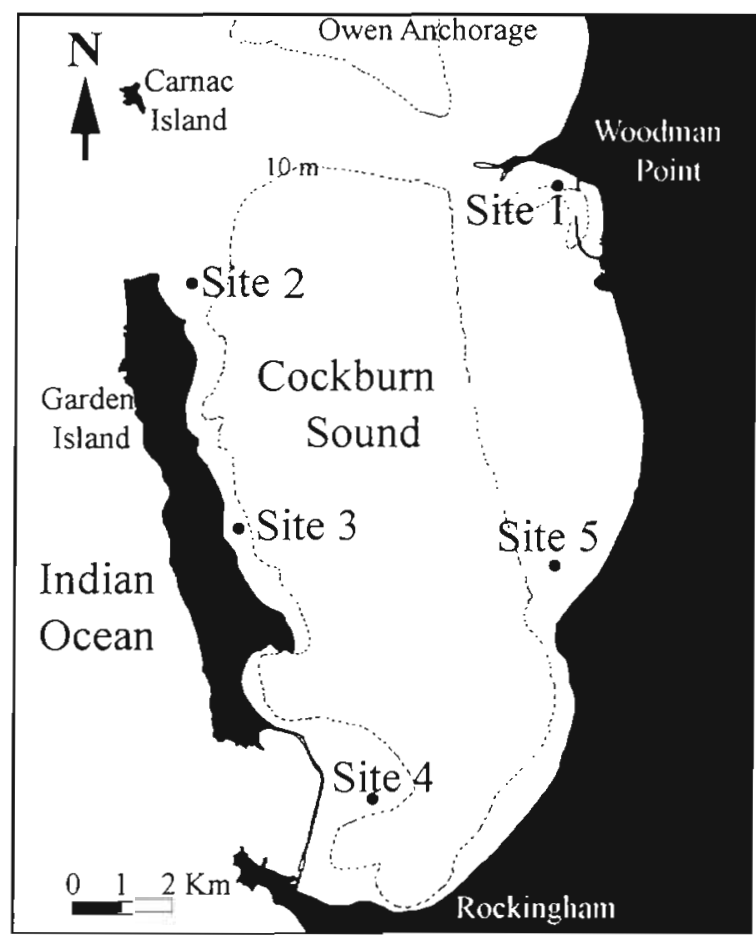

Fig. 1. Sampling sites within Cockburn Sound, Western Aus tralia. Site 1: Woodman Point; Site 2: Luscombe Bay; Site 3: Buchanan Bay; Site 4: Southern Flats; Site 5: Kwinana 
mined by averaging the concentrations at the 3 water depths $\left( \pm 0.06 \mu \mathrm{g} \mathrm{l}^{-1}\right)$.

Because the seagrasses Amphibolis antarctica (Labill.) Sonder et Aschers. and Heterozostera tasmanica (Martens ex. Aschers.) only occurred at Luscombe Bay and Woodman Point respectively, they could only be sampled at these sites. Sabella spallanzanil, an introduced polychaete suspension-feeder discovered in Cockburn Sound during the present study, was sampled at the Southern Flats only. The study component for suspension-feeders occurred during winter (September)

At each site, 3 replicate samples of suspension-feeders were collected by means of SCUBA, using a $0.25 \mathrm{~m}^{2}$ quadrate, randomly placed in the respective habitats. All macro-suspension-feeders (ascidians, sponges, crinoids, bivalves, bryozoans, etc.) were collected from the quadrate. In the laboratory the samples were sieved over a $2 \mathrm{~mm}$ sieve and stored at $--20^{\circ} \mathrm{C}$

Macro-suspension-feeders were sorted to genus and, where possible, species level. Each item was dried to constant weight at $\sim 80^{\circ} \mathrm{C}$ and ashed for $4 \mathrm{~h}$ at $\sim 550^{\circ} \mathrm{C}$ to determine ash free dry weight (AFDW).

A smaller quadrate $\left(0.04 \mathrm{~m}^{2}\right)$ was used to sample the epifaunal suspension-feeder component on seagrass leaves, as well as the infaunal and epibenthic components. All leaf and rhizome material, as well as substrate down to where the roots reached, was collected within this quadrate and later separated into leaf, rhizome and epiphyte components. The dry weight of each was determined to provide a measure of habitat density. A sub-sample of $\sim 10$ leaves was used to estimate the epifaunal suspension-feeder component. Its density was then related to a $0.04 \mathrm{~m}^{2}$ seagrass surface area through the dry weight ratio of sample and sub-sample. Infaunal and epibenthic suspension-feeders were collected by sieving the substrate over a $2 \mathrm{~mm}$ sieve.

Epifaunal suspension-feeders on seagrass leaves (hydroids, bryozoans, spirorbids, barnacles, amphipods, etc.) were counted under a dissecting microscope and identified to species level where possible. Spirorbids, barnacles and bryozoans were measured with a graticule. Of the amphipods, their tubular housings were counted, after ascertaining that the majority of tubes were occupied. Of the colonial organisms (hydroids, bryozoans), the number of polyps and zooids (n) was used as a measure of density. The weight of epifaunal suspension-feeders on seagrass leaves was not estimated.

Data analysis. A nested experimental design was followed (habitats within sites). Spatial patterns in macroand epifaunal suspension-feeders were analysed with a balanced hierarchical ANOVA (Minitab Inc. 1993) on each of the phyla as well as on the total of all filterfeeders. Where data were heterogeneous and assump- tions for parametric testing were violated (as tested by a Cochran's test), data were $\log (1+x)$ transformed before analysis (Fowler \& Cohen 1990). All values are expressed in means $\pm \mathrm{SE}$.

Patterns in mean chl a values were analysed by a 1 way ANOVA and a Tukey test (Fowler \& Cohen 1990). Observations were compared with spatial patterns in suspension-feeders.

Estimated clearance rates. The clearance rate (the volume of water cleared of suspended particles per unit of time) is equal to the filtration rate (the volume of water transported through the filters of the feeding organ per unit of time) when particles are so large that they cannot pass the pores of the filter (e.g. Jørgensen 1966).

Estimates of the clearance rates of suspensionfeeding communities were obtained by combining their mean biomass densities with clearance rates as reported in the literature, although it is recognised that such values are dependent on a range of variables (see 'Discussion'). An average water temperature of $20^{\circ} \mathrm{C}$ was used for these calculations. Cockburn Sound has a mean winter temperature of $17^{\circ} \mathrm{C}$, and $22^{\circ} \mathrm{C}$ in summer (e.g. Pearce 1986).

Filtration rates of a number of ascidians are available within the literature (e.g. Holmes 1973, Fiala-Médioni 1974, Randløv \& Riisgård 1979, Robbins 1983, Klumpp 1984, Petersen \& Riisgård 1992) and range between 10.2 and $26.0 \mathrm{l} \mathrm{g}^{-1}$ AFDW d $\mathrm{d}^{-1}$ for Pyura stolonifera (Klumpp 1984) to $145.7 \mathrm{l} \mathrm{g}^{-1}$ AFDW d $\mathrm{d}^{-1}$ for Microcosmus sabatieri (Fiala-Médioni 1974). We applied clearance rates of Petersen \& Riisgård (1992), based on Ciona intestinalis from European waters

$$
F_{\max }=118 \mathrm{DW}^{0.68}+1.21(T-15)
$$

where $F_{\max }$ is the maximum filtration rate in $\mathrm{ml} \mathrm{min}^{-1}$ ind. ${ }^{-1}$, DW is dry weight in $g$ and $T$ is temperature. An ascidian clearance rate of $96 \mathrm{l} \mathrm{g}^{-1}$ AFDW d-1 was applied for ascidians in Cockburn Sound (mean ascidian DW: $15 \mathrm{~g}$ ind. ${ }^{-1}$; AFDW: $75 \%$ of DW). Initial estimates of the $F_{\max }$ of some small ascidians (AFDW: $0.18 \mathrm{~g}$ for Polycarpa nigricans, $0.27 \mathrm{~g}$ for Pyura australia, $0.39 \mathrm{~g}$ for Polycarpa clavata, $0.51 \mathrm{~g}$ for Polycarpa viridis) which dominate in the seagrass meadows are between 30 and $120 \mathrm{l} \mathrm{g}^{-1}$ AFDW d $\mathrm{d}^{-1}$ (Lemmens et al. 1996). However, further measurements (Petersen \& Lemmens unpubl. data) demonstrate that their $F_{\max }$ may be closer to those of Ciona intestinalis, while clearance rates per unit of total AFDW of larger ascidians (e.g. Herdmania momus, Phallusia obesa), which dominate on soft bottom substrate, may be substantially lower $\left(25-30 \mathrm{l} \mathrm{g}^{-1}\right.$ AFDW d ${ }^{-1}$ ), largely due to their relatively heavy theca.

Clapin (1996) recently determined the filtering capacity of Sabella spallanzanii under laboratory conditions and found that its filtration rate increases with 
temperature from $1.7 \mathrm{I} \mathrm{h}^{-1} \mathrm{~g}^{-1} \mathrm{DW}$ bodv at $17^{\circ} \mathrm{C}$ to almost $4 \mathrm{l} \mathrm{h}^{-1} \mathrm{~g}^{-1} \mathrm{DW}_{\text {body }}$ at $22^{\circ} \mathrm{C}$ (dry weights expressed as weight of organisms, after removal from their tubes). Body DW in S. spallanzanii relates to total DW according to $\mathrm{DW}_{\text {totai }}=3.92 \mathrm{DW}_{\text {body }}$ (Clapin unpubl. data; $\mathrm{R}^{2}=$ $0.67)$ and $A F D W_{\text {total }}=0.66 \mathrm{DW}_{\text {totol }}$ (Clapin unpubl, $\mathrm{R}^{2}=$ 0.45). Thus, $F_{\max }$ of $2.7 \mathrm{I} \mathrm{h}^{-1} \mathrm{~g}^{-1} \mathrm{DW}_{\text {body }}$ at $20^{\circ} \mathrm{C}$ (Clapin 1996) relates to a filtration capacity of $\sim 1.04 \mathrm{l} \mathrm{h}^{-1} \mathrm{~g}^{-1}$ AFDW total or $25.0 \mathrm{I} \mathrm{g}^{-1}$ AFDW d $\mathrm{d}^{-1}$ at $20^{\circ} \mathrm{C}$. This is considerably lower than that of Sabella penicillus, which reaches $7.44 \mathrm{l} \mathrm{h}^{-1}$ for a 'standard' $65 \mathrm{mg}$ DW $S$. penicillus, or $114.5 \mathrm{I} \mathrm{h}^{-1} \mathrm{~g}^{-1} \mathrm{DW}$ at $17^{\circ} \mathrm{C}$ (Riisgård \& Ivarsson 1990). Adult S. spallanzanii in Cockburn Sound (1.0 to $2.5 \mathrm{~g}$ DW) have a comparable filtering capacity of between 3 and $7.5 \mathrm{l}$ ind..$^{-1} \mathrm{~h}^{-1}$ at $22^{\circ} \mathrm{C}$, despite their much larger size (Clapin 1996).

Infaunal polychaetes have a clearance rate of between 2.2 and $88.1 \mathrm{~g} \mathrm{~g}^{-1}$ AFDW d ${ }^{-1}$ (e.g. Dales 1957, 1961, Buhr 1976, Klockner 1978, Shumway et al. 1988, Riisgård 1989, 1991, Riisgård et al. 1992). We applied a mean clearance rate of $23.8 \mathrm{~g} \mathrm{~g}^{-1}$ AFDW d $\mathrm{d}^{-1}$ for infaunal polychaetes.

Measurements of the clearance rates of bivalves are numerous (e.g. Haranghy 1942, Jørgensen 1943, 1990, Allen 1962, Coughlan 1964, Hughes 1969. Winter 1969, 1973, 1978, Ali 1970, Widdows \& Bayne 1971, Bayne et al. 1976, Kiørboe \& Møhlenberg 1981, Harvey \& Luoma 1984, Calahan et al. 1989, Vismann 1990, Cole et al. 1992, MacDonald \& Ward 1994). We used a mean clearance rate of $45.7 \mathrm{~g} \mathrm{~g}^{-1}$ AFDW d ${ }^{-1}$ (see Wilson et al. 1993).

Although a number of echinoderms are considered suspension-feeders (e.g. Rutman \& Fishelson 1969, Warner \& Woodley 1975, Labarbera 1978), we did not attempt to quantify their clearance rate per unit of AFDW.

Best \& Thorpe (1986) estimated epifaunal bryozoan zooids to filter 3.6 to $220.8 \mathrm{ml} \mathrm{zooid}^{-1} \mathrm{~d}^{-1}$. Bullivant (1968) calculated a feeding rate of 3.6 to $25.2 \mathrm{ml} \mathrm{zooid}^{-1}$ $\mathrm{d}^{-1}$, or 333.6 to $2308.8 \mathrm{ml} \mathrm{g}^{-1} \mathrm{DW} \mathrm{d} \mathrm{d}^{-1}$ at phytoplankton

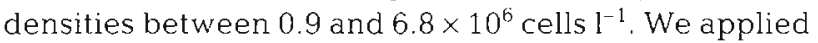
a mean value of $24 \mathrm{ml}_{\text {zooid }}{ }^{-1} \mathrm{~d}^{-1}$ for bryozoans, and $10 \mathrm{l}$ $\mathrm{g}^{-1}$ AFDW d $\mathrm{d}^{-1}$ (assuming AFDW is $10 \%$ of DW)

The clearance rate of sponges was based on measurements by Riisgård et al. (1993) on 2 European. sponges from the genus Halichondria (mean clearance rate: $80.4 \mathrm{l} \mathrm{g}^{-1}$ AFDW d $\mathrm{d}^{-1}$ for $H$. panicea and similar values for $H$. urceolus at $12^{\circ} \mathrm{C}$ ). However, mean temperatures in Cockburn Sound are between 16 and $24^{\circ} \mathrm{C}$ (Pearce 1986 ) so that clearance rates may be substantially higher for sponges in Cockburn Sound. Few other data are available on the filtration rate of marine sponges (Reiswig 1971, 1974, 1975, Frost 1978, Jørgensen 1983, Stuart \& Klumpp 1984, Thomassen \& Riisgård 1995); clearance rates of between 40.9 and $134.5 \mathrm{~g} \mathrm{~g}^{-1} \mathrm{DW} \mathrm{d} \mathrm{d}^{-1}$ were measured for sponges (see Thomassen \& Riisgård 1995), or approximately 84.3 to
$277.1 \mathrm{l} \mathrm{g}^{-1}$ AFDW d $\mathrm{d}^{-1}$, when using an AFDW/DW ratio of 2 (see Riisgård et al. 1993). We applied a clearance rate of $100 \mathrm{l} \mathrm{g}^{-1}$ AFDW d ${ }^{-1}$ for sponges.

The diet of the Mediterranean hydroid Campanula everta consists largely $(88 \%)$ of particulate organic matter between 30 and $80 \mu \mathrm{m}$ in size, of which, by weight, $54 \%$ consisted of zooplankton (Coma et al. 1995). C everta consumed 1860 food items polyp ${ }^{-1} \mathrm{~d}^{-1}$, of which $97 \%$ was particulate organic matter other than zooplankton (Coma et al. 1995). Thus, although hydroids are not - strictly speaking - filter-feeders, they do affect the densities of suspended organic matter. Assuming a mean phytoplankton density of between 160 and 260 cells $\mathrm{ml}^{-1}$ for Cockburn Sound (S. Helleren pers. comm.), these hydroids are estimated to clear $\sim 10 \mathrm{ml}^{\text {polyp }} \mathrm{d}^{-1} \mathrm{~d}^{-1}$. However, at an estimated par-

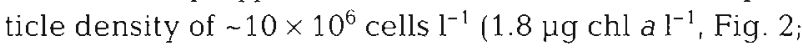
$180 \mathrm{fg}$ chl a cell ${ }^{-1}$; Thompson et al. 1989), hydroids are

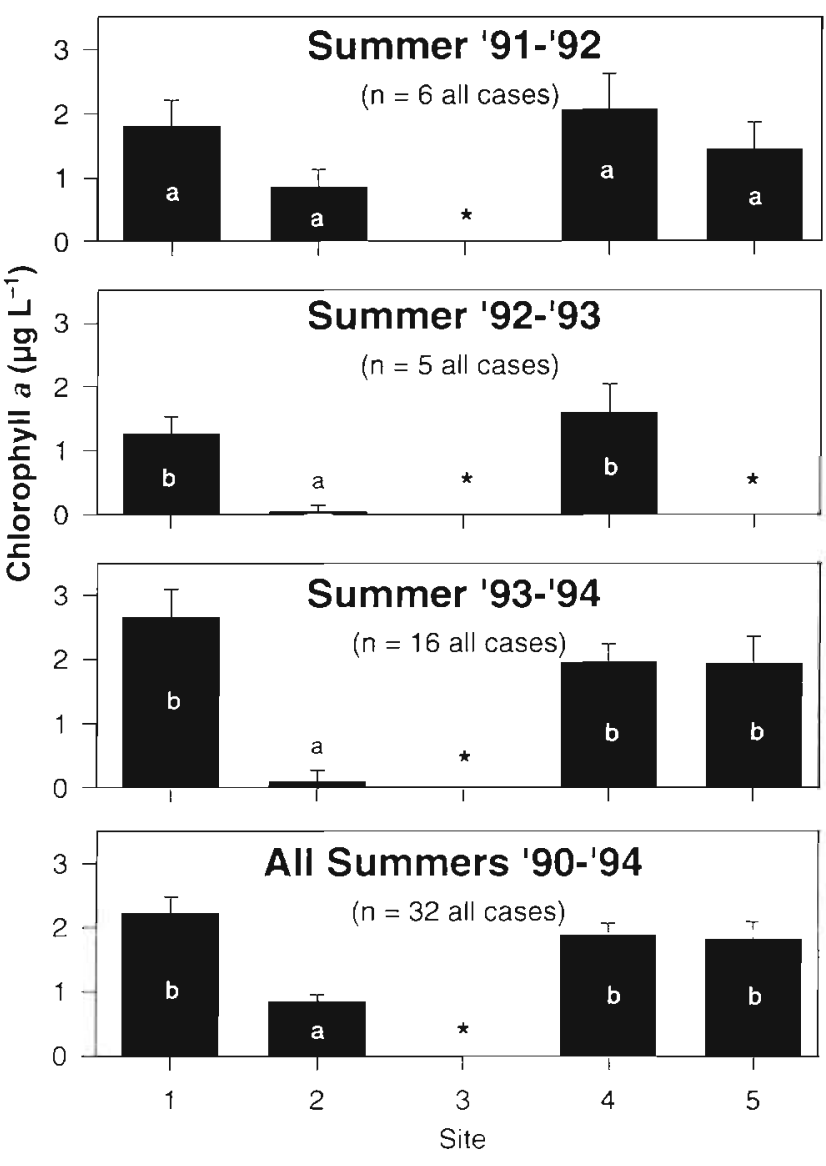

Fig. 2. Mean and standard error of summer chl a concentrations at the study sites between 1990 and 1994. Significant differences between means are represented by different characters (ANOVA and Tukey test; $\alpha=0.05$ ). In all but one year, the western site (2) had significantly lower concentrations than the eastern sites $(1,4$ and 5). For site locations see Fig. 1. 'Missing data 
estimated to clear only $\sim 0.2 \mathrm{ml}$ polyp $\mathrm{p}^{-1} \mathrm{~d}^{-1}$ : clearance rate estimates of these organisms are heavily dependent on particle densities and digestion rates. On the other hand, Barange \& Gili (1988) estimated that the hydroid Eudendrium racemosum consumes only 4.3 zooplankton items polyp $\mathrm{p}^{-1} \mathrm{~d}^{-1}$ Our calculations assume a clearance rate of $1 \mathrm{ml}$ polyp $\mathrm{p}^{-1} \mathrm{~d}^{-1}$ for hydroids.

Spirorbid clearance rates are based on Dales (1957), who estimated the clearance rate of Spirorbis borealis (mean wet wt: $0.24 \mathrm{mg}$ ind. ${ }^{-1}$ ) to be $0.23 \mathrm{ml}$ ind..$^{-1} \mathrm{~h}^{-1}$, or $55 \mathrm{ml}$ spirorbid ${ }^{-1} \mathrm{~d}^{-1}$, but did not provide a correction for size differences or water temperatures.

Estimates of barnacle clearance rates were based on Anderson (1981), who reported a rate of $0.4 \mathrm{l} \mathrm{h}^{-1}$ for Balanus perforatus at temperatures between 15 and $23^{\circ} \mathrm{C}$. However, Anderson's (1981) specimens were of adult size ( $-37 \mathrm{~mm}$ diameter, $\sim 16 \mathrm{~mm}$ height), while epifaunal barnacles from Cockburn Sound are $\sim 1 \mathrm{~mm}$ in height. Since the clearance rate is dependent on the volume of the body cavity (Anderson 1981), the clearance rate of epifaunal Elminius covertus was estimated to be approximately $0.1 \mathrm{ml} \mathrm{h}^{-1}$ or $2.4 \mathrm{ml} \mathrm{d}^{-1}$ (estimated volumes of body cavities: $3 \mathrm{ml}$ for $B$. perforatus; $0.75 \mu \mathrm{l}$ for $E$. covertus).

Blinn \& Johnson (1982) reported a filtration rate of $15.6 \mathrm{ml} \mathrm{d}^{-1}$ for the freshwater amphipod Hyalella montezuma. Forster-Smith \& Shillaker (1977) estimated pumping rates of the tubulous amphipod Corophium bonelli (body length $-3.5 \mathrm{~mm}$ ) to be between 6.0 and $7.4 \mathrm{ml} \mathrm{h}^{-1}$ and of Lembos websteri (body length $-4.3 \mathrm{~mm}$ ) between 0.7 and $1.3 \mathrm{ml} \mathrm{h}^{-1}$, while pumping between 51 and $86 \%$ of the total time, at water temperatures of 9.5 to $11^{\circ} \mathrm{C}$ (no conversion for water temperature is given). These rates are, surprisingly, comparable to those of the much smaller cladocerans and copepods (see Jørgensen 1966). A mean clearance rate of $-39.4 \mathrm{ml} \mathrm{d}^{-1}$ was applied for amphipods.

\section{RESULTS}

\section{Chl a levels}

A consistent trend was evident in summer chl a concentrations throughout Cockburn Sound between 1990 and 1994 (Fig. 2). Between 1990 and 1994, Site 2 had consistently lower concentrations than the other sites measured in that year (no data are available for Site 3 , Buchanan Bay). This difference was significant in 1990/91 and 1993/94, and in pooled dates over
1990-94 (Fig. 2). It corresponds to a simple differentiation between northwestern (Site 2; Luscombe Bay) and southeastern sites (Sites 1, 4 and 5; Woodman Point, Southern Flats and Kwinana respectively) and is likely to be related to nutrient releases in the southeast of the Sound. No significant differences were apparent among the southeastern sites in any of the years.

On the basis of all 4 summers' data, the mean concentration at Site 2 (Luscombe Bay) was $0.85 \mu \mathrm{g} \mathrm{l}^{-1}$ and was significantly (ANOVA, $\mathrm{p}<0.0001, \mathrm{n}=32$ ) lower than the concentrations at the other sites $(1.82,1.89$ and $2.22 \mathrm{\mu g} \mathrm{l}^{-1}$ at Sites 5, 4 and 1, respectively; Fig. 2).

\section{Macro-filter-feeders}

The mean biomass of macro-filter-feeders in the Posidonia meadows was $21.9 \mathrm{~g} \mathrm{AFDW} \mathrm{m}^{-2}$, which is significantly (Table 1, Fig. 3) higher than that for bare sediment (3.0 g AFDW m-2; Fig. 4). Although overall differences among sites were not significant, differences in the biomass of ascidians ( $p=0.004)$, annelids $(\mathrm{p}=0.003)$, and echinoderms $(\mathrm{p}=0.011)$ were significant (Table 1). Furthermore, Posidonia meadows were significantly different from 'bare' sediment in ascidian $(p<0.0005)$, sponge $(p<0.02)$ and echinoderm $(p<$ $0.005)$ biomass; among-habitat differences were not significant for bivalves, annelids and bryozoans ( $p>$ 0.05) (Table 1).

Ascidians dominated in Posidonia meadows at Site 1 (Woodman Point), Site 3 (Buchanan Bay) and Site 5 (Kwinana); ascidian biomass was at least twice as high at Kwinana (Site $5: 35.8 \pm 3.3 \mathrm{~g} \mathrm{AFDW} \mathrm{m}^{-2}$ ) than at the other sites (Fig. 3). Herdmania momus was the dominant ascidian at Woodman Point (Site 1), Buchanan Bay (Site 3) and Kwinana (Site 5). The ascidian genera 


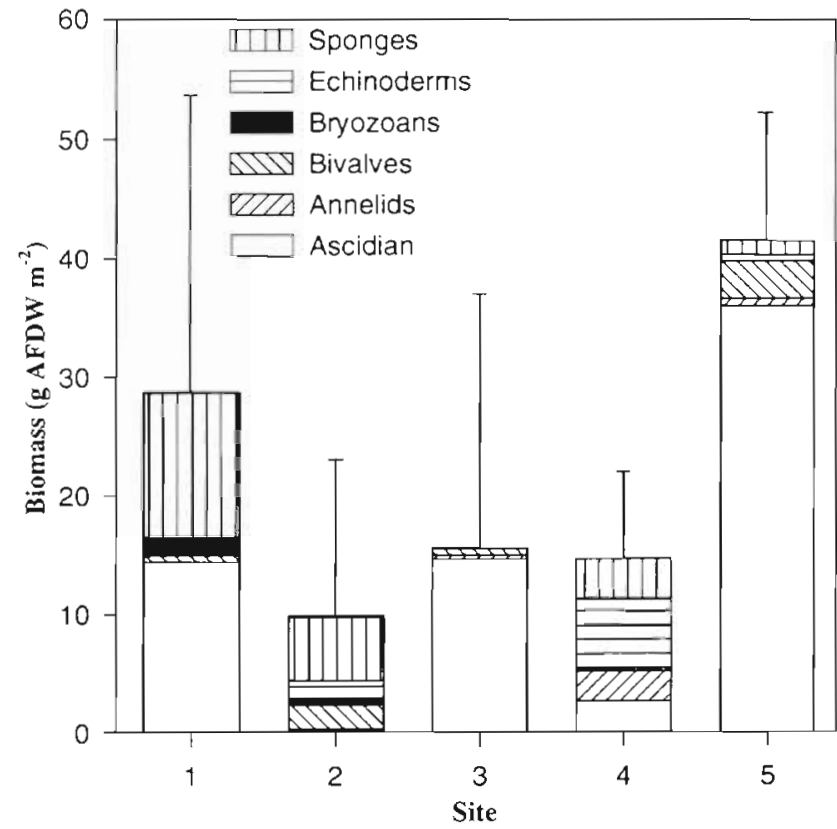

Fig. 3. Mean AFDW $\mathrm{m}^{-2}$ of macro-filter-feeders in Posidonia meadows of Cockburn Sound (with SE). For site locations see Fig. 1

Phallusia (Sites 4 and 5), Botrylloides (Sites 1, 3 and 5) and Polycarpa (Sites 1 and 5) (see Kott 1985 for descriptions) were represented at some of the southeastern sites. The poriferan genus Tethya (see Hooper \& Weidenmayer 1994) was the dominant sponge at Buchanan Bay (Site 3: $5.3 \pm 4.7 \mathrm{~g} \mathrm{AFDW} \mathrm{m}^{-2}$ ) and Kwinana (Site 5: $1.1 \pm 0.6 \mathrm{~g} \mathrm{AFDW} \mathrm{m}^{-2}$ ); a range of other sponge species were found in Posidonia meadows at Woodman Point (Site 1) and the Southern Flats (Site 4). Infaunal annelid species (see Wells 1978 , Hutchings 1982 for species) were common at the Southern Flats (Site 4) but less common in Posidonia meadows at other sites (Fig. 3). The bivalves Pinna bicolor, Cardita incrassata and Paphies elongata made up a considerable biomass at Luscombe Bay (Site 2) and Kwinana (Site 5; Fig 3). Epibenthic bryozoans were only important at Woodman Point (Site 1), A range of infaunal annelids (predominantly Neireida, Nephytidie) dominated in most bare sediments, although bivalves ( $P$. bicolor, $C$. incrassata, $P$. elongata) and ascidians (e.g. Polycarpa viridis) were common at Sites 3 (Buchanan Bay) and 5 (Kwinana) (Fig 4) Variance between replicates was relatively low $k 5 \%$ of total variance; Table 1). There was a weak linear correlation between seagrass biomass and macro-filterfeeder biomass $\left(r^{2}=0.46\right)$, and between rhizome biomass and macro-filter-feeder biomass $\left(r^{2}=0.33\right)$.

During the present study it was discovered that at the Southern Flats (Site 4) a large area previously occupied by seagrass meadows was densely covered

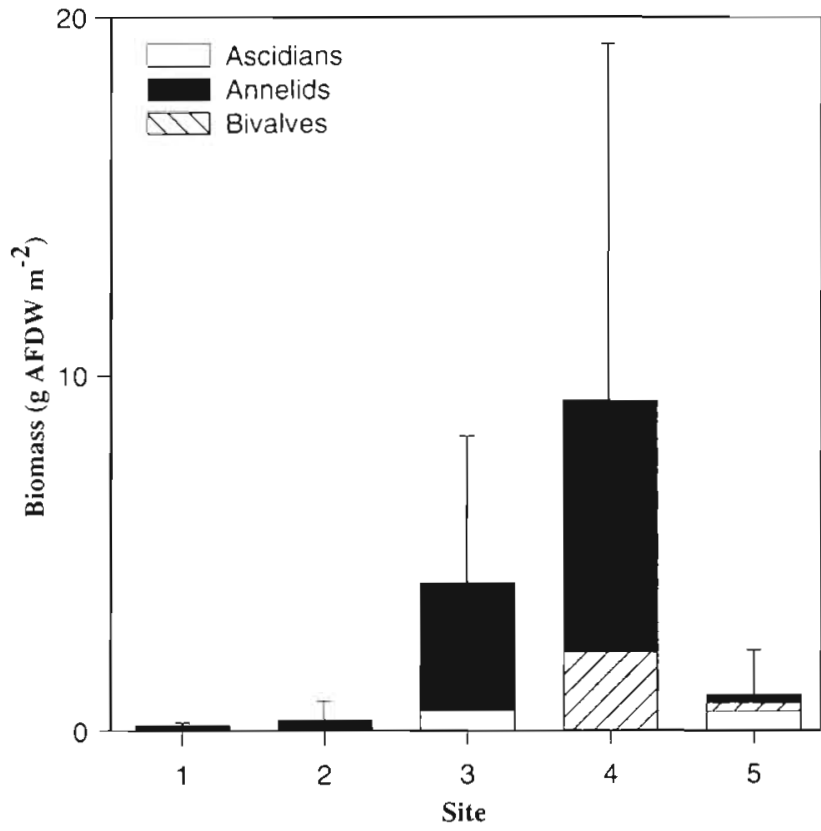

Fig. 4. Mean AFDW $\mathrm{m}^{-2}$ of macro-filter-feeders in bare sediment of Cockburn Sound (with SE). For site locations see Fig. 1

with the polychaete Sabella spallanzanii, a species introduced from European waters (see Clapin \& Evans 1995). Within this area the species reached a biomass of $458.9 \pm 72.5 \mathrm{~g}$ AFDW $\mathrm{m}^{-2}$. Although the sabellid polychaete dominated, both in numbers and in biomass, ascidians (predominantly the large Herdmania momus and Phallusia obesa; $79.2 \pm 41.8 \mathrm{~g} \mathrm{AFDW} \mathrm{m}^{-2}$ ) and bivalves (predominantly Pina bicolor; $34.5 \pm 34.3 \mathrm{~g}$ AFDW $\mathrm{m}^{-2}$ ) were also abundant within this habitat far more abundant than in the nearby Posidonia meadows (Fig. 3).

Well-cleveloped Amphibolis and Heterozostera beds were found only at Site 2 (Luscombe Bay) and Site 1 (Woodman Point) respectively. Heterozostera at Woodman Point (Site 1) supported a substantially lower biomass of large suspension-feeders than the Posidonia meadows at this site $\left(1.2\right.$ and $28.6 \mathrm{~g} \mathrm{AFDW} \mathrm{m}^{-2}$ respectively; see Fig. 3 and Table 5), while both Amphibolis and Posidonia at Luscombe Bay (Site 2) supported low numbers of macro-suspension-feeders $(2.3$ and $9.7 \mathrm{~g}$ AFDW m ${ }^{-2}$ respectively; see Fig. 3 and Table 5). Small annelids were dominant in Heterozostera at Woodman Point (Site 1. $0.9 \pm 0.9 \mathrm{~g} \mathrm{AFDW}^{-2}$ ) and Amphibolis at Luscombe Bay (Site 2: $1.2 \pm 0.8 \mathrm{~g} \mathrm{AFDW} \mathrm{m}^{-2}$ ).

\section{Epifaunal filter-feeders}

The numbers of epifaunal filter-feeders on Posidonia leaves was high, compared with the number of macro- 
Table 2. Diversity indices for suspension-feeding macro-invertebrates within 5 marine habitats of Cockburn Sound, based on 3 replicate samples. $S$ : species count (infaunal polychaetes counted as 1 species); $\mathrm{n} \mathrm{m}^{-2}$ : mean number of macro-suspension-feeders per $\mathrm{m}^{2}$ over 3 replicates

\begin{tabular}{|lccccc|}
\hline Site & $\begin{array}{c}\text { Posidonia } \\
\text { meadows } \\
\mathrm{n} \mathrm{m} \mathrm{m}^{-2}(\mathrm{~S})\end{array}$ & Bare sediment & $\begin{array}{c}\text { Amphibolis } \\
\text { meadows } \\
\mathrm{n} \mathrm{m}^{-2}(S)\end{array}$ & $\begin{array}{c}\text { Heterozosiera } \\
\text { meadows } \\
\mathrm{n} \mathrm{m} \mathrm{m}^{-2}(S)\end{array}$ & $\begin{array}{c}\text { Sabella } \\
\text { spallanzanii } \\
\mathrm{n} \mathrm{m} \mathrm{m}^{-2}(S)\end{array}$ \\
\hline 1 (Woodman Point) & $47(11)$ & $6(1)$ & - & $8(4)$ & - \\
2 (Luscombe Bay) & $4(6)$ & $2(1)$ & $12(5)$ & - & - \\
3 (Buchanan Bay) & $16(7)$ & $4(4)$ & - & - & - \\
4 (Southern Flats) & $11(8)$ & $1994(4)$ & $3(4)$ & - & - \\
5 (Kwinana) & $11(1)$ & $(4)$ & - & - \\
\hline
\end{tabular}

filter-feeders (Tables $2 \& 3$ ). Five invertebrate groups were found on these leaves: hydroids, bryozoans, spirorbids, amphipods and barnacles. Of these, over $75 \%$ were hydroids (Fig. 5). The hydroid species Monotheca australis and Pynotheca producta were the most common; Orthopyxis tincta, Plumularia filicaulis and Diphasia tubatheca were less common (cf. Watson 1992). Tube-dwelling corophiid amhipods (predominantly Ericthonius sp.; see Barnard \& Karaman 1991) were numerous at Woodman Point (Site 1: $1.4 \times 10^{5} \pm$ $0.5 \times 10^{5}$ ind. $\mathrm{m}^{-2}$ ) and the Southern Flats (Site $4: 2.3 \times$ $10^{5} \pm 0.9 \times 10^{5}$ ind. $\mathrm{m}^{-2}$ ), but far less numerous on Posidonia leaves from other sites (Sites 2, 3 and 5: $105 \pm$ 147 ind. $\mathrm{m}^{-2}$; Fig. 5). Similarly, the barnacle Elminius sp. was common on Posidonia leaves at Woodman Point (Site 1: $1.3 \times 10^{4} \pm 0.6 \times 10^{4}$ ind. $\mathrm{m}^{-2}$ ), almost absent at Luscombe Bay (Site 2: $52 \pm 26$ ind. $\mathrm{m}^{-2}$ ) and

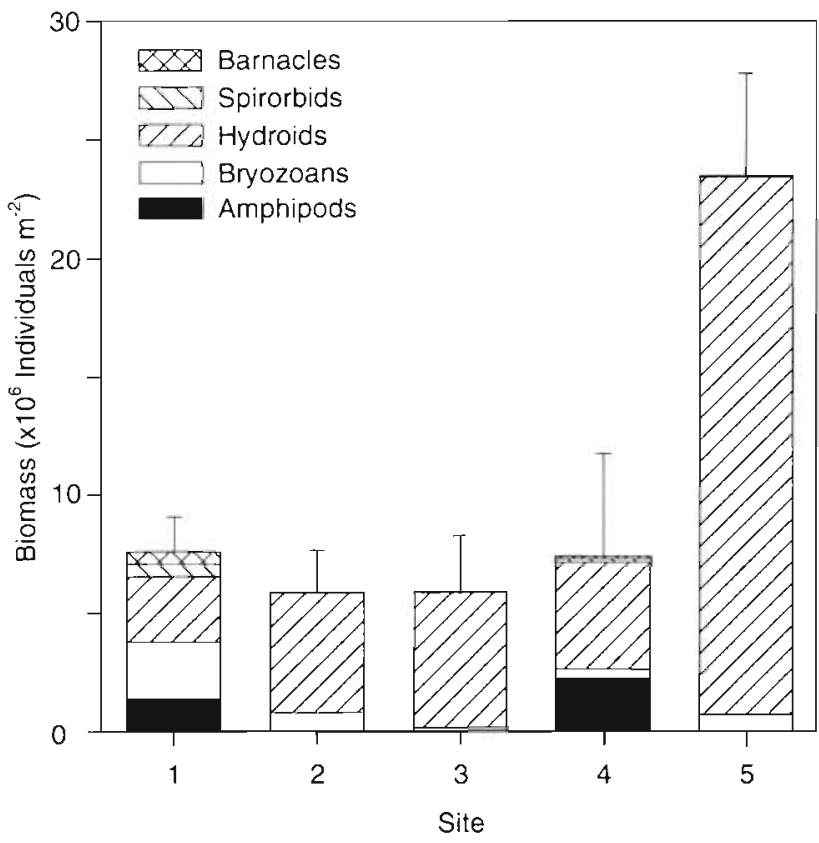

Fig. 5. Mean number of epifaunal filter-feeder units (individuals: polyps, zooids) per $\mathrm{m}^{2}$ Posidonia seagrass in Cockburn Sound (with SE) moderately abundant at the other 3 sites (Sites 3, 4 and 5: mean density of $4.5 \times 10^{3} \pm 2.6 \times 10^{3}$ ind. $\mathrm{m}^{-2}$; Fig. 5).

Differences in epifaunal densities on Posidonia leaves were highly significant between sites for barnacles (predominately Elminius sp.; $p<0.0005$ ), spirorbids ( $p<0.005$ ) and amphipods ( $p<0.0005$; Table 4$)$, although there were fewer spirorbids and barnacles than hydroids. Hydroid densities were higher at Kwinana (Site 5: $2.27 \times 10^{6} \pm 0.52 \times 10^{6}$ polyps $\mathrm{m}^{-2}$ ) than at the other sites (mean: $0.45 \times 10^{6} \pm 0.06 \times 10^{6}$ polyps $\mathrm{m}^{-2}$; Fig. 5), but the level of significance of differences between sites was low ( $p=0.055$; Table 3). Bryozoans did not demonstrate significant betweensite differences ( $p>0.05$; Table 4)

Spirorbids, barnacles and amphipods were abundant on tubes of Sabella spallanzanii from the Southern Flats (Site 4: $4.1 \times 10^{5} \pm 1.1 \times 10^{5}$ ind. $\mathrm{m}^{-2}$ ). At Luscombe Bay (Site 2) the Amphibolis meadows supported a variety of epiphytes, with numbers reaching similar densities $\left(7.1 \times 10^{5} \pm 2.1 \times 10^{5}\right.$ ind. $\left.\mathrm{m}^{-2}\right)$ to those on Posidonia meadows at this site (Table 3 ). However, Heterozostera meadows from Woodman Point (Site 1) supported considerably lower densities of epifaunal suspension-feeders (total n m ${ }^{-2}: 0.78 \times 10^{5} \pm 0.62 \times 10^{5}$ ) than Posidonia leaves (total n m $\mathrm{m}^{-2}: 7.6 \times 10^{5} \pm 1.5 \times 10^{5}$ ). Here, hydroids were most important, but samples demonstrated considerable fluctuations between replicates (range: $1.2 \times 10^{3}$ to $1.9 \times 10^{5}$ polyps $\mathrm{m}^{-2}$ ).

Table 3. Diversity indices for epifaunal suspension-feeders on Posidonia leaves from Cockburn Sound, based on 3 replicate

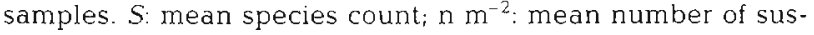
pension-feeding units (polyps, zooids, individuals) within $1 \mathrm{~m}^{2}$ over 3 replicates

\begin{tabular}{|lcc|}
\hline Site & $\begin{array}{c}\mathrm{n} \mathrm{m}^{-2} \\
(\mathrm{df}=4 ; F=2.58)\end{array}$ & $\begin{array}{c}S \\
(\mathrm{df}=4 ; F=3.36)\end{array}$ \\
\hline 1 (Woodman Point) & $7.6 \times 10^{5} \pm 1.5 \times 10^{5}$ & 8.0 \\
2 (Luscombe Bay) & $5.9 \times 10^{5} \pm 1.8 \times 10^{5}$ & 12.0 \\
3 (Buchanan Bay) & $5.8 \times 10^{5} \pm 2.4 \times 10^{5}$ & 7.7 \\
4 (Southern Flats) & $7.4 \times 10^{5} \pm 4.3 \times 10^{5}$ & 9.3 \\
5 (Kwinana) & $23.4 \times 10^{5} \pm 5.2 \times 10^{5}$ & 9.3 \\
\hline
\end{tabular}


Table 4. Analysis of vanance for the density $\left(\mathrm{n} \mathrm{m}^{-2}\right)$ of epifaunal suspension-feeders on Posidonia leaves from 5 sites and 3 replicates for each of the 6 phyla as well as the total number of filter-feeders. Data were $\log (1+x)$ transformed

\begin{tabular}{|c|c|c|c|c|c|}
\hline \multirow{2}{*}{$\begin{array}{l}\text { Source of } \\
\text { variance }\end{array}$} & \multicolumn{3}{|c|}{ Site } & \multicolumn{2}{|c|}{ Errot } \\
\hline & $\mathrm{df}$ & SS & $F$ & $\mathrm{df}$ & SS \\
\hline Hydroids & 4 & 1.782 & 3.35 & 10 & 1.332 \\
\hline Bryozoans & 4 & 12.670 & 2.69 & 10 & 11.780 \\
\hline Spirorbids & 4 & 8.207 & $13.29^{\circ}$ & 10 & 1.543 \\
\hline Barnacles & 4 & 18.743 & $13.41 \cdots$ & 10 & 3.494 \\
\hline Amphipods & 4 & 58.076 & $14.70 \cdots$ & 10 & 9.878 \\
\hline All animals & 4 & 0.924 & 2.58 & 10 & 0.893 \\
\hline
\end{tabular}

\section{Species diversity}

The abundance and diversity of macro-suspensionfeeders was relatively high in the Posidonia meadows (Table 2). Only at the Southern Flats did the mean number of organisms in 'bare' sediment exceed that of Posidonia meadows, mainly due to the numbers of infaunal polychaetes.

The species diversity ( $S$ ) of macro-suspension-feeders in Amphibolis meadows in Luscombe Bay $(S=5)$ and the Sabella patch on the Southern Flats $(S=9)$ was comparable to that in Posidonia meadows (range 6 to 11 ; Table 2), but was low in the Heterozostera tasmanica meadows at Woodman Point ( $S=4)$. The species diversity of epifaunal suspension-feeders in Posidonia meadows was relatively constant among the sites (Table 3), although hydroids dominated at Woodman Point, while at Luscombe Bay all phyla were more evenly represented (Fig. 5).

\section{DISCUSSION}

\section{Chl a levels in Cockburn Sound}

The chl a concentration displayed a consistent gradient, from low in the west to high in the east of Cockburn Sound. The east-west chl a gradient was a consistent feature over the 4 summers for which data were collected. An almost identical chl a gradient was observed in the Sound as far back as 1977 (Chiffings \& McComb 1981). Several reports (e.g Cary et al. 1991 . Lavery $1994 \mathrm{a}$, b) attributed this distribution pattern to the location of the nutrient sources in the southeast corner of the Sound and a wind driven counter-clockwise water current within the Sound under typical summer sea breeze conditions (e.g. Steedman \& Craig 1983) Industrial waste is discharged on the eastern side of the Sound, while the western side (bordered by
Garden Island) is undeveloped. Together the data indicate that the observed summer chlorophyll gradient is a persistent environmental variable that could influence the distribution of biota in the Sound

\section{Spatial patterns in suspension-feeder densities}

Clear spatial patterns were observed in suspensionfeeding communities. In Posidonia meadows the highest densities of macro-suspension-feeders were observed at the eastern sites (Woodman Point and near Kwinana; Sites 1 and 5), while the highest densities of epifaunal suspension-feeders were near Kwinana. This spatial pattern positively corresponds to a large extent with levels of nutrient enrichment (expressed in chl a concentrations) in the water and a high epiphyte biomass on the seagrass leaves (Silberstein et al. 1986, Borowitzka \& Lethbridge 1989). Nutrient enrichment is generally highest in the southeastern section of Cockburn Sound (e.g. Cary et al. 1991).

It seems plausible that the spatial patterns in nutrient inputs, phytoplankton, epiphyte biomass and suspension-feeding communities are related; a significant relationship between nutrient loads and chl a levels in Cockburn Sound has already been demonstrated (Cary et al. 1991; also see Chiffings 1979). Furthermore, an increase in suspended organic material, including phytoplarkton, would be able to support a higher biomass of suspension-feeders. They, in turn, would affect the densities of suspended organic material, as in San Francisco Bay (Cloern 1982).

However, since the western and eastern parts of Cockburn Sound differ in a wide range of variables, including wave exposure and invertebrate recruitment rates, and suspension-feeders also feed on other particulate organic matter (e.g. Stuart et al. 1982, Seiderer \& Newell 1985, Judge et al. 1993), suspension-feeder biomass cannot simply be linked to one particular variable such as chl a levels. Furthermore, such a relationship would be difficult to establish in the field.

\section{Filtering capacity of suspension-feeding communities}

Ecological data on the biomass of the main suspension-feeders in a marine habitat can be combined with physiological data on the filtration capacity of the animals to estimate the filtering capacity of the habitat (e.g. Petersen \& Riisgård 1992). However, the filtering capacity of suspension-feeding communities is dependent on such factors as species-specific differences, water temperature, animal size, food concentrations, environmental conditions, flow rates, the boundary 
effect (where flow rates decrease near the substrate), stratification, etc. (see Bayne et al. 1976 and Riisgård \& Larsen 1995 for overviews) and seasonal changes in the biomass of suspension-feeders. Other sources of error in estimating the filtration capacity of marine habitats may result from particle size selection le.g. sponges generally ingest smaller particles than other suspension-feeders; Reiswig 1975, Stuart \& Klumpp 1984). Most measurements of filtration rates in the literature are of temperate organisms from the northern hemisphere, although a number of studies on ascidians, sponges and bivalves from southern Africa (which has similar environmental conditions) are available (e.g. Griffiths 1980, Stuart 1982, Stuart et al. 1982, Klumpp 1984, Stuart \& Klumpp 1984, Seiderer \& Newell 1985, 1988, Matthews et al. 1989). Few data are available on the - often endemic - suspension-feeders from southwest Australia, which may find an optimum under substantially different environmental conditions (e.g. Lemmens et al. 1996), so that extrapolation of the available data is necessary.

The time to achieve a $50 \%$ decrease in phytoplankton densities is a more correct way of presenting the filtering capacity of suspension-feeding communities than the volume processed per unit of time, since levels of suspended material do decrease linearly with time. At a given clearance rate $(C)$ and a known water volume $\left(V_{w}\right)$, the time $(t)$ to achieve a $50 \%$ decrease in food density (where the final concentration, $C_{t}$, is 0.5 times the concentration at $\left.t=0, C_{0}\right)$ can be calculated from the formula: $C=\left(V_{\mathrm{w}} / t\right) \ln \left(C_{0} / C_{1}\right)$ (see Petersen \& Riisgård 1992, Riisgård et al. 1993). However, in this calculation it is assumed that there is no replacement of water and complete mixing of the water column; this is rarely the case, as generally a current is present, and both stratification and the existence of a boundary layer demonstrate incomplete mixing of the water column.

The biomass of the invertebrate suspension-feeding groups and their filtering capacities (drawn from the literature; see 'Materials and methods') provide an estimate of the filtering capacity of the community (Table 5). However, clearance rates are dependent on a range of variables (see above), so must be used cautiously. Nonetheless, such calculations may demonstrate the relative importance of the various communities in clearing the water column of organic material.

Posidonia meadows can, on average, turn over the equivalent of the water column above them $(-5 \mathrm{~m}$ water depth or $\sim 5000 \mathrm{l}$ seawater $\mathrm{m}^{-2}$ habitat) approximately daily, while communities on bare sediment $(\sim 5 \mathrm{~m}$ depth) will turn over the water column above them approximately once a month. Suspension-feeding communities in Posidonia meadows have a substantially higher filtering capacity (possibly over 25 times higher; Table 5) than those on non-vegetated soft- bottom substrate ('bare' sediment). This is only to a small extent due to macro- and infaunal suspensionfeeders ( $24 \%$ of the total filtering capacity; Table 5); the more numerous epifauna (hydroids, bryozoans, barnacles and amphipods) are far more important (76\%; Table 5). Epifauna are uncommon on bare sediment.

Ascidians and sponges are the main macro-suspension-feeders in Posidonia meadows (Table 5), while bivalves and small, burrowing annelids provide most of the filtering capacity of bare sediment (Table 5). However, when dense communities of the large polychaete Sabella spallanzanii invade the bare sediment, they substantially enhance the filtering capacity. Sabellid polychaetes at the Southern Flats have a similar filtering capacity to the macro-filter-feeders in Posidonia meadows, although the epifauna on the polychaete tubes provides a substantial part of this filtering capacity (Table 5). Our estimates of the filtering

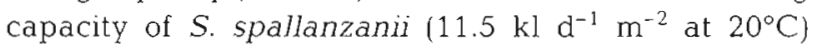
compare well with more detailed recent estimates by Clapin (1996), who estimated these polychaete communities on the Southern Flats of Cockburn Sound to represent a filtering capacity of $23 \mathrm{kl} \mathrm{d}^{-1} \mathrm{~m}^{-2}$ in summer $\left(22^{\circ} \mathrm{C}\right)$ and $10 \mathrm{kl} \mathrm{d}{ }^{-1} \mathrm{~m}^{-2}$ in winter $\left(17^{\circ} \mathrm{C}\right)$. However, other organisms within these communities more than double the total filtering capacity to about $26 \mathrm{kl}$ $\mathrm{d}^{-1} \mathrm{~m}^{-2}$ (Table 5). Our estimates indicate that $S$. spallanzanii communities at the Southern Flats possibly turn over the water column above them $(-5 \mathrm{~m})$ several times daily and constitute a considerably higher filtering capacity than the Posidonia meadows they have replaced.

Amphibolis and Heterozostera meadows were found at only 1 site each. The Amphibolis meadows at Luscombe Bay constitute a similar filtering capacity to that of Posidonia meadows (Table 5) and will turn over the water column above them $(\sim 5 \mathrm{~m})$ in about a day. However, due to morphological differences between Posidonia and Amphibolis, there are differences in the ratios of the various epifaunal suspension-feeders: at Luscombe Bay bryozoans and hydroids are more common on Amphibolis leaves (Table 5, Fig. 5), possibly because they tend to be more common near the leaf sheaths (J Lemmens pers. obs.), which are more favourably placed in the water current than in Posidonia (see remarks by Keough 1986). However, this is surprising in view of the relatively high turnover times of Amphibolis leaves (between 28 and $40 \mathrm{~d}$ for Amphibolis antarctica compared with 65 and $125 \mathrm{~d}$ for Posidonia australis and $73.7 \mathrm{~d}$ for Heterozostera tasmanica; Halophila ovalis has a mean life-span of 11 to $24 \mathrm{~d}$; e.g Borowitzka \& Lethbridge 1989), which would allow little time for the development of epifaunal suspension-feeders. It should, however, be noted that at Luscombe Bay sponge and ascidian biomass is relatively 


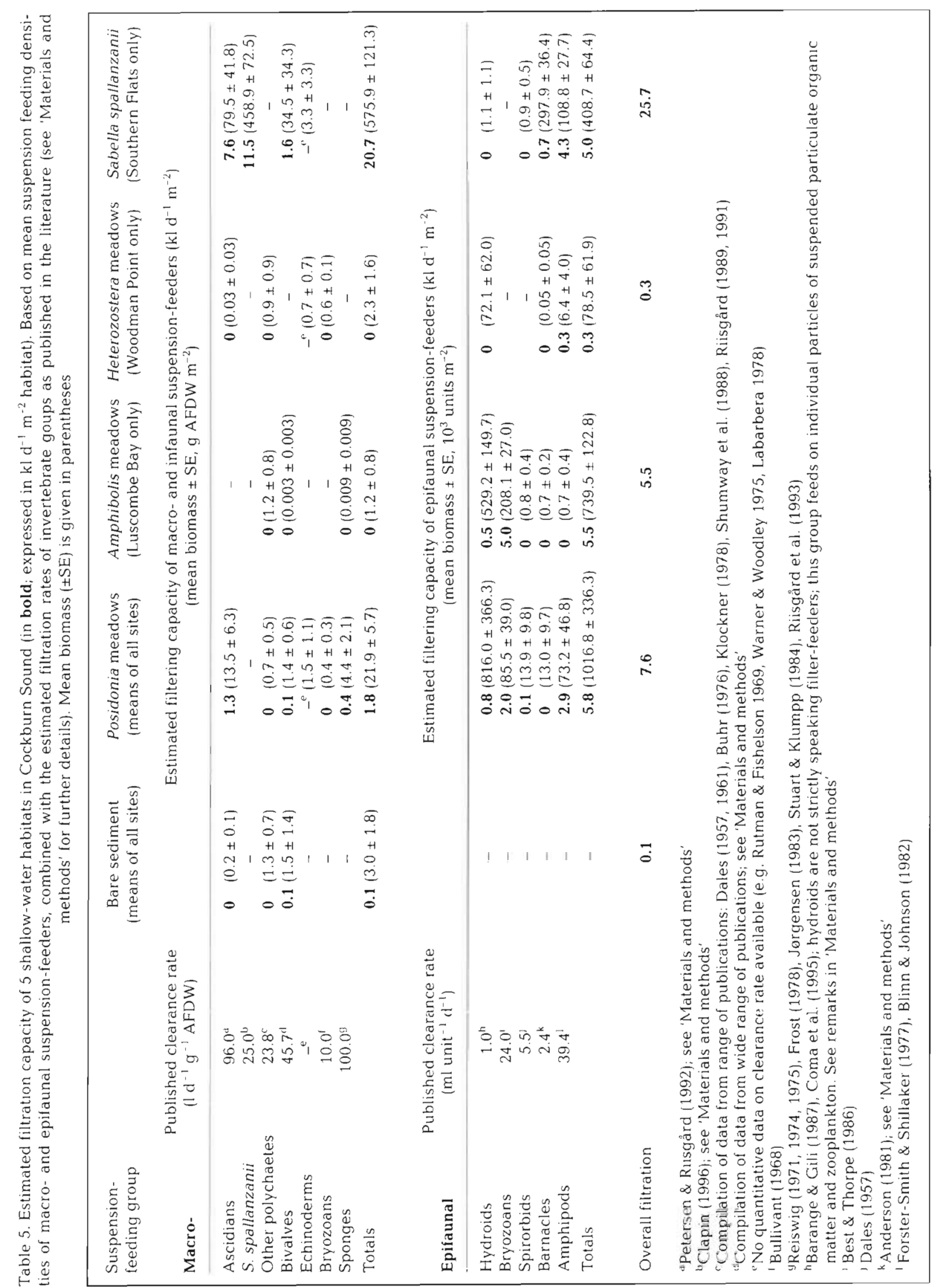


low in both Amphibolis and Posidonia meadows (Table 5. Fig. 3), and also contributes relatively little to the filtering capacity of Posidonia meadows here.

Heterozostera meadows at Woodman Point support low densities of suspension-feeding infauna. Hydroids and amphipods are few, as are macro-filter-feeders, while infaunal polychaetes are relatively rare within these meadows. If complete mixing of the water column occurs, these communities are estimated to turn over the water column above them $(-5 \mathrm{~m})$ approximately twice a month, slightly more than unvegetated substrate (Table 5).

Although our biomass data, especially on epifaunal organisms, are based on small samples, were collected on 1 occasion only (September 1994), and have relatively high error margins (see Table 5), they give an indication of the contribution of the various components to the total filtering capacity of the communities in Cockburn Sound. In the Posidonia meadows, for instance, the epifauna $\left(\sim 1 \times 10^{6}\right.$ ind. $\left.\mathrm{m}^{-2}\right)$ are estimated to provide about $76 \%$ of the total filtering capacity of these meadows ( $\sim 6 \mathrm{kl} \mathrm{m}^{-2}$ seagrass meadow $\mathrm{d}^{-1}$; Table 5$)$. The epifaunal suspension-feeders make an unexpectedly high contribution to the total filtering capacity.

Although hydroids are not, strictly speaking, filterfeeders, and our estimates of their filtering capacity (Table 5) are disputable (see 'Materials and methods'), they may have a substantial impact on densities of suspended organic material. Coma et al. (1995) noted that, for example, the hydroid Campanularia everta - on the algae Halimeda tuna in the western Mediterranean Sea - may ingest approximately $4 \times 10^{3}$ prey $\mathrm{m}^{-2} \mathrm{~d}^{-1}$ in summer and $8 \times 10^{5}$ prey $\mathrm{m}^{-2} \mathrm{~d}^{-1}$ in winter or $1528 \mathrm{mg} \mathrm{C} \mathrm{m} \mathrm{mr}^{-1}, 88 \%$ of which may be detritus rather than zooplankton.

The biomass of the deep basin $(>10 \mathrm{~m}$ ) of Cockburn Sound is dominated by molluscs $(89.6 \%$ of individuals; $72.2 \%$ of biomass), of which $95.7 \%$ are infaunal suspension-feeders (Wells \& Threlfall 1980). Polychaetes and crustaceans together make up a further $20.3 \%$ of the biomass (Wells 1978). These organisms have a biomass of between 336 and $2027 \mathrm{~g}$ wet wt $\mathrm{m}^{-2}$ (Wells \& Threlfall 1980) and may thus add considerably to the total filtering capacity of Cockburn Sound. Jetties and pylons also support a considerable suspension-feeder biomass - with a substantial filtering capacity - which thus far has largely been overlooked (e.g. Clapin 1996).

\section{Differences between habitats in density of suspension-feeder communities}

The shallow-water soft-bottom communities in Cockburn Sound have different suspension-feeder communities. Posidonia communities support a far higher bio- mass in suspension-feeders than unvegetated soft-bottom substrates: sufficient to turn over the water column above them in less than a day (at least potentially), which would have a considerable impact on local concentrations of suspended organic matter (Table 5). Suspension-feeders associated with unvegetated soft-bottom substrate, on the other hand, are unlikely to have a significant impact on local concentrations of suspended organic matter, except where they have been invaded by the introduced polychaete Sabella spallanzanii (Table 5). These observations correspond with other reports. In Princess Royal Harbour, Albany, Western Australia, for example, the loss of seagrass meadows has resulted in a decline in the benthic marine invertebrate biomass by $82 \%$, from 1937 to $340 \mathrm{t}$, although most of these were gastropod molluscs and crustaceans (Kirkman et al. 1991, Wells et al. 1991).

Limited data on Amphibolis and Heterozostera meadows indicate that the former may have a similar filtering capacity to Posidonia meadows, although largely through the high densities in bryozoans and other epifauna: macro-suspension-feeder biomass is relatively low in both Posidonia and Amphibolis meadows at Luscombe Bay (Table 5, Fig. 3) Heterozostera meadows have a far lower filtration capacity than both Posidonia and Amphibolis meadows - similar to unvegetated substrate (Table 5) - due to their lower biomass of suspension-feeders. This may be due to the relatively small leaf area of Heterozostera, resulting in less substrate for epifaunal suspension-feeders. In addition, Heterozostera occurs in Cockburn Sound where it is often associated with Halophila - in relatively coarse and unstable substrates where epifauna may be subject to abrasion.

The biomass of suspension-feeders is generally not constant over time. Highest hydroid densities in southwest Australia are reached during August, when water temperature is beginning to rise from a winter low of $\sim 16^{\circ} \mathrm{C}$ (Watson 1992). The present data set only provides an estimate of suspension-feeder biomass in winter. These may be quite different from the biomass in summer.

The importance of suspension-feeding communities in controlling phytoplankton levels in shallow, semienclosed environments has been suggested by a number of studies (e.g. Buss \& Jackson 1981, Cloern 1982, Fréchette \& Bourget 1985, Dame et al. 1989, Asmus \& Asmus 1991, Hily 1991, Alpine \& Cloern 1992). However, our study suggests that epifaunal suspensionfeeders may have a far greater filtering capacity than generally accepted (Table 5).

The vertical distribution of seagrass is to a considerable extent determined by light penetration (e.g. Backman \& Barilotti 1976), so factors affecting light penetration (depth, concentration of suspended organic and 
inorganic material, epiphytic growth) play a large part in determining the distribution of these seagrasses. Seagrass meadows (Posidonia and Amphibolis) support high densities of suspension-feeders which - by feeding on phytoplankton and other suspended particulate organic matter such as detritus (e.g. Stuart et al. 1982, Judge et al. 1993) - could improve light penetration, thereby partly counteracting the negative effects of eutrophication on the vertical distribution of seagrasses (although excessive epifauna itself can reduce light penetration to the leaves). It is uncertain if suspensionfeeders are also capable of controlling settlement of epiphytes on seagrasses, by reducing the densities of algal spores in the water column. However, loss of Posidonia and Amphibolis meadows leads to a considerable loss of suspension-feeder communities, thereby compounding the negative effects of eutrophication and further complicating revegetation by seagrasses. Pioneer species such as Heterozostera and Halophila support a fraction of the invertebrate suspensionfeeders in Posidonia and Amphibolis meadows.

Acknowledgements. This study is part of the CSIRO Coastal Zone Program Filter-feeder Project, and was undertaken in collaboration with the Edith Cowan University (ECU) and the Western Australian Department of Environmental Protection (DEP). CSIRO Marine Laboratories provided logistical support and laboratory space; DEP collected the chl a data and provided additional boat time. We thank Ed Greenway (ECU) for collecting data on epifaunal filter-feeders; Dr Hugh Kirkman (CSIRO) for sharing his ideas which formed the basis for this study, and for his constructive comments; Dr Jeanette Watson (Marine Science \& Ecology Environmental Consultants, Victoria, Australia) for identifying representative hydroids; Drs Graham Edgar, Alan Butler, Vivienne Mawson and a number of anonymous referees for their constructive comments.

\section{LITERATURE CITED}

Ali RM (1970) The influence of suspension, density and temperature on the filtration rate of Hiatella arctica. Mar Biol 6:291-302

Allen JA (1962) Preliminary experiments on the feeding and cxcretion of bivalves using Phaeodactylum labelled with P:- J Mar Biol Ass UK 42:609-623

Alpine AE, Cloern JE (1992) Trophic interactions and direct physical effects control phytoplankton biomass and production in an estuary. Limnol Oceanogr 37:946-955

Anderson DT (1981) Cirral activity and feeding in the barnacle Balanus perforatus Bruguiere (Balanidae), with comments on the evolution of feeding mechanisms in thoracican cirripides. Phil Trans R Soc Lond Ser B Biol Sci 291:411-449

Asmus RM, Asmus H (1991) Mussel beds: limiting or promoting phytoplankton? J Exp Mar B1ol Ecol 148:215-232

Backman TW, Barilotti DC (1976) Irradiance reduction: effects on standing crops of the eelgrass, Zostera marina, in a coastal lagoon. Mar Biol 34:351-353

Barange M, Gili JM (1988) Feeding cycles and prey capture in Eudendrium racemosum (Cavolini, 1785). J Exp Mar Biol Ecol 115:281-293
Barnard JL, Karaman G (1991) The families and genera of marine gammaridean amphipoda except marine gammaroids). Rec Aust Mus 13:209-241

Bayne BL. Thompson RJ, Widdows J (1976) Physiology I. In: Bayne BL (ed) Marine mussels, their ecology and physiology. Cambridge University Press, Cambridge, p 121-206

Best MA. Thorpe JP (1986) Effects of food particle concentration on feeding current velocity in six species of marine Bryozoa. Mar Biol 93:255-262

Blinn D W, Johnson D B (1982) Filter-feeding Fralella montezuma, an unusual behaviour for a freshwater amphipod. Freshwat Invertebr Biol 1:48-52

Borowitzka MA, Lethbridge RC (1989). Seagrass epiphytes. In: Larkum AWD, McComb AJ, Shepherd SA (eds) Seagrasses: a treatise on the biology of seagrasses with special reference to the Australasian region, Chap 14. Elsevier, Amsterdam, p 458-499

Buhr KJ (1976) Suspension-feeding and assimilation efficiency in Lanice conchilega (Polychaete). Mar Biol 38: 373-383

Bullivant JS (1968) The rate of feeding of the bryozoan Zoobotryon verticillatum. NZ J Mar Freshwat Res 2: $111-134$

Buss LW, Jackson JBC (1981) Planktonic food availability and suspension-feeder abundance: evidence of in situ depletion. J Exp Mar Biol Ecol 49:151-161

Calahan JA, Siddall SE, Luckenbach MW (1989) Effects of flow velocity, food concentration and particle flux on growth rates of juvenile bay scallops Argopecten irradians. J Exp Mar Biol Ecol 129:45-60

Cambridge ML (1979) Technical Report on Seagrass, Cockburn Sound Study. Report No. 7, Department of Conservation \& Environment, Perth

Cambridge ML, McComb AJ (1986) The loss of seagrass from Cockburn Sound, Western Australia. II. Possible causes of seagrass decline. Aquat Bot 24:269-285

Cary JL, Masini RJ (1995) Water quality survey in Cockburn Sound, Warmbro Sound and Sepia Depression between January 1991 and February 1992. Data Report SMCWS ECOL-10, Department of Environmental Protection, Perth

Cary JL, Simpson CJ, Chase S (1991) Water quality in Cockburn Sound. Technical Series No. 47, Environmental Protection Authority, Perth

Chiffings AW (1979) Cockburn Sound environmental study. Technical report on nutrient enrichment and phytoplankton, Report No. 3. Department of Conservation and Environment, Perth

Chiffings AW, McComb AJ (1981) Boundaries in phytoplankton populations. Proc Ecol Soc Aust 11:27-38

Chittleborough RG (1970) Conservation of Cockburn Sound a case study. Australian Conservation Foundation, Parkville, Victoria

Clapin Gi (1996) The filtration rate, oxygen consumption and biomass of the introduced polchaete Sabella spallanzanit Gmelun within Cockburn Sound. Honours thesis, Edith Cowan University, Joondalup

Clapin G, Evans DR (1995) The status of the introduced marine fan worm, Sabella cf. spallanzanii (Gmelin, 1791) in Western Australia: a preliminary investigation. Technical Report No. 2, CSIRO Centre for Research on Introduced Marine Pests, Hobart

Cloern JE (1982) Does the benthos control phytoplankton biomass in South San Francisco Bay? Mar Ecol Prog Ser 9: $191-202$

Cole BE, Thompson JK, Cloern JE (1992) Measurement of fil tration rates by infaunal bivalves in a recirculating flume Mar Biol 113(2):219-225 
Coma R, Gili JM, Zabala M (1995) Trophic ecology of a benthic marine hydroid, Campanularia everta. Mar Ecol Prog Ser 119:211-220

Coughlan JAA (1964) A direct method for determining the pumping rates of siphonate bivalves. I Cons Perm Int Explor Mer 29:205-213

Dales RP (1957) Some quantitative aspects of feeding in sabellid and sepulid fan worms. J Mar Biol Ass UK 36: 309-316

Dales RP (1961) Observations on the respiration of the sabellid polychaete Schizobranchia insignis. Biol Bull Mar Biol Lab, Woods Hole 121:82-91

Dame RF, Spurrier JD, Wolaver TG (1989) Carbon, nitrogen and phosphorus processing by an oyster reef. Mar Ecol Prog Ser 54:249-256

Dennison WC, Alberte RS (1982) Photosynthetic responses of Zostera marina $L$. (eelgrass) to in situ manipulations of light intensity. Oecologia 55:137-144

Fiala-Médioni A (1974) Ethologie alimentaire d'invertébrés benthiques filtreurs (ascidies). II. Variations des taux de filtration et de digestion en fonction de l'espèce. Mar Biol 28:199-206

Fitzpatrick J, Kirkman $H$ (1995) The effects of prolonged shading stress on the growth and survival of the seagrass Posidonia australis in Jervis Bay, NSW. Mar Ecol Prog Ser $127: 279-289$

Forster-Smith RL, Shillaker RO (1977) Tube irrigation by Lembos weberi Bate and Corophium bonelli Milne Edwards (Crustacea: Amphipoda). J Exp Mar Biol Ecol 26:289-296

Fowler J, Cohen L (1990) Practical statistics for field biology. John Wiley \& Sons, New York

Fréchette M, Bourget E (1985) Energy flow between the pelagic and benthic zones: factors controlling particulate organic matter available to an intertidal mussel bed. Can J Fish Aquat Sci 42:1158-1165

Frost TM (1978) In situ measurements of the clearance rates for the freshwater sponge Spongilla lacustris. Limnol Oceanogr 23:1034-1039

Griffiths RJ (1980) Filtration, respiration, and assimilation in the black mussel Choromytilus meridionalis. Mar Ecol Prog Ser 3:63-70

Haranghy L (1942) Die Muschelvergiftung als biologisches Problem auf Grund der neueren diesbezuglichen Ursachenforschung. Helgoländer Wiss Meeresunters 2: $279-352$

Harvey RW, Luoma SN (1984) The role of bacterial exopolymer and suspended bacteria in the nutrition of the depositfeeding clam Macoma balthica. J Mar Res 42:957-968

Hily C (1991) Is the activity of benthic suspension-feeders a factor controlling water quality in the Bay of Brest? Mar Ecol Prog Ser 69:179-188

Holmes N (1973) Water transport in the ascidians Styela clava and Ascidiella aspera (Müller). J Exp Mar Biol Ecol 11: $1-13$

Hooper JNA, Wiedenmayer F (1994) Porifera. In: Wells A (ed) Zoological catalogue of Australia, Vol 12. CSIRO Australia, Melbourne

Hughes RN (1969) A study of feeding in Scrobicularia plana. J Mar Biol Ass UK 49:805-823

Hutchings P (1982) Bristleworms (Phylum Annelida). In: Shepherd SA, Thomas IM (eds) Marine invertebrates of southern Australia, Part 1. DJ Woolman, Government Printer, South Australia, p 228-298

Jeffrey SW, Humprey GF (1975) New spectrophotometric equations for determining chlorophylls $-a, b, c$ and $c 2$ in higher plants, algae and natural phytoplankton. Biochem Physiol Pflanz 167:191-194
Jorgensen CB (1943) On the water transport through the gills of bivalves. Acta Physiol Scand 5:297-304

Jorgensen CB (1966) Biology of suspension-feeding. Pergamon Press, Oxford

Jorgensen CB (1983) Fluid mechanical aspects of suspension feeding. Mar Ecol Prog Ser 11:89-103

Jorgensen CB (1990) Bivalve filter feeding: hydrodynamics, bioenergetics, physiology and ecology. Olsen \& Olsen, Fredensborg

Judge ML, Coen LD, Heck KL (1993) Does Mercenaria mercenaria encounter elevated food levels in seagrass beds? Results from a novel technique to collect suspended food resources. Mar Ecol Prog Ser 92:141-150

Keough M (1986) The distribution of a bryozoan on seagrass blades: settlement, growth and mortality. Ecology 67(4): $846-857$

Kiørboe T, Møhlenberg F (1981) Particle selection in suspension-feeding bivalves. Mar Ecol Prog Ser 5:291-296

Kirkman H, Humphries P, Manning R (1991) The epibenthic fauna of seagrass beds and bare sand in Princess Royal Harbour and King George Sound, Albany, southwest Australia. In: Wells FE, Walker DI, Kirkman H, Lethbridge R (eds) The marine flora and fauna of Albany, Western Australia, Vol 2. Proc 3rd Int Mar Biol Workshop. Western Australian Museum, Perth, p 553-564

Klockner K (1978) Zur Okologie von Pomatoceros triqueter (Serpulidae, Polychaeta). Helgoländer Wiss Meeresunters 31:219-223

Klumpp DW (1984) Nutritional ecology of the ascidian Pyura stolonifera: influence of body-size, food quantity and quality on filter-feeding, respiration, assimilation efficiency and energy balance. Mar Ecol Prog Ser 19:269-284

Kott P (1985) The Australian Ascidiacea. Part I, Phlebobranchia and Stolidobranchia. Mem Queensl Mus 23:1-440

Labarbera M (1978) Particle capture by a Pacific brittle star experimental test of the aerosol suspension feeding model. Science 201:1147-1149

Lavery P (1994a) Changes in seagrass cover. Commissioned Report 1994-05. Department of Environmental Management, Edith Cowan University, Perth

Lavery P (1994b) The current state of seagrass health in the Success Bank to Warnbro Sound region. Commissioned Report 1994-06. Department of Environmental Management, Edith Cowan University, Perth

Lemmens JWTJ, Kirkpatrick D, Thompson P (1996) The clearance rates of four ascidians from. Marmion Lagoon, Western Australia. In: Kuo J, Phillips RC, Walker Dl, Kirkman H (eds) Seagrass biology: Proceedings of an International Workshop. Rottnest Island, WA, 25-29 Jan. '96. Faculty of Sciences, University of Western Australia, Perth, p $277-282$

MacDonald BA, Ward JE (1994) Variation in food quality and particle selectivity in the sea scallop Placopecten magellanicus (Mollusca: Bivalvia). Mar Ecol Prog Ser 108: $251-264$

Matthews S, Lucas MI, Stenton-Dozey JME, Brown AC (1989) Clearance and yield of bacterioplankton and particulates for two suspension-feeding infaunal bivalves, Donax serra Röding and Mactra lilacea. J Exp Mar Biol Ecol 125: $219-234$

Minitab Inc (1993) Minitab reference manual release 9 for Windows. Sowers Printing Co, Lebanon, PA

Pearce A (1986) Sea temperatures of Western Australia. FINS Fish News 19(2):6-9

Petersen JK, Riisgård HU (1992) Filtration capacity of the ascidian Ciona intestinalis and its grazing impact in a shallow fjord. Mar Ecol Prog Ser 88:9-17 
Randlov A, Riisgård HU (1979) Efficiency of particle retention and filtration rate in four species of ascidians. Mar Ecol Prog Ser 1:55-59

Reiswig HM (1971) Particle feeding in natural populations of three marine demosponges. Biol Bull Mar Biol Lab, Woods Hole 141:568-591

Reiswig HM (1974) Water transport, respiration and energetics of three tropical marine sponges. J Exp Mar Biol Ecol $14: 231-249$

Reiswig HM (1975) Bacteria as food for temperate-water marine sponges. Can J Zool 53:582-589

Riisgård HU (1989) Properties and energy cost of the muscular piston pump in the suspension-feeding polychaete Chaetopterus variopedatus. Mar Ecol Prog Ser 56:157-168

Riisgård HU (1991) Suspension feeding in the polychaete Nereis diversicolor. Mar Ecol Prog Ser 70:29-37

Riisgård HU, Ivarsson NM (1990) The crown-filament pump of the suspension-feeding polychaete Sabella penicillus: filtration, effects of temperature, and energy cost. Mar Ecol Prog Ser 62:249-257

Riisgård HU, Larsen PS (1995) Filter-feeding in marine macroinvertebrates: pump characteristics, modelling, and energy cost. Biol Rev 70:67-106

Riisgård HU, Thomassen S, Jakobsen H, Meeks JM, Larsen PS (1993) Suspension-feeding in marine sponges Halichondria panicea and Halichondria urceolis: effects of temperature on filtration rate and energy cost of pumping. Mar Ecol Prog Ser 96:177-188

Riisgård HU, Vedel A, Boyle H, Larsen PS (1992) Filter-net structure and pumping activity in the polychaete Nereis diversicolor: effects of temperature and pump-modelling. Mar Ecol Prog Ser 83:79-89

Robbins IJ (1983) The effects of body size, temperature, and suspension density on the filtration and ingestion of inorganic particulate suspensions by ascidians. J Exp Mar Biol Ecol 70:65-78

Rutman J, Fishelson L (1969) Food composition and feeding behavior of shallow-water crinoids at Eilat (Red Sea). Mar Biol 3:46-57

Seiderer LJ, Newell RC (1985) Relative significance of phytoplankton, bacteria and plant detritus as carbon and nitrogen resources for the kelp bed filter-feeder Choromytilus meridionalis. Mar Ecol Prog Ser 22:127-139

Seiderer LJ, Newell RC (1988) Exploitation of phytoplankton as a food resource by the kelp bed ascidian Pyura stolonifera. Mar Ecol Prog Ser 50:107-115

Shumway SE, Bogdanowicz C, Dean D (1988) Oxygen consumption and feeding rates of the sabellid polychaete. Myxicola infundibulum (Renier). Comp Biochem Physiol 90A(3):425-428

Silberstein K, Chiffings AW, McComb AJ (1986) The loss of seagrass in Cockburn Sound, Western Australia. IIJ. The effects of epiphytes on productivity of Posidonua australis Hook. F. Aquat Bot 24:355-371

Simpson CJ, Butt JS, Cary JL, D'Adamo ND, Masini RJ, Mills DA (1993) Southern Metropolitan Coastal Waters Study 1991-94. Environmental Protection Authority, Perth

Steedman RK, Craig PD (1983) Wind-driven circulation of Cockburn Sound. Aust J Mar Freshwat Res 34:187-212

Stuart V (1982) Absorbed ration, respiratory costs and resultant scope for growth in the mussel Aulacomya ater

This article was submitted to the editor
(Molina) fed on a diet of kelp detritus of different ages. Mar Biol Lett 3(4-5):289-306

Stuart V, Field JG. Newell RC (1982) Evidence for absorption of kelp detritus by the ribbed mussel Aulacomya ater using a new ${ }^{51} \mathrm{Cr}$-labelled microsphere technique. Mar Ecol Prog Ser 9:263-271

Stuart V, Klumpp DW (1984). Evidence for food-resource partitioning by kelp-bed filter feeders. Mar Ecol Prog Ser 16: $27-37$

Thomassen S, Riisgard HU (1995) Growth and energetics of the sponge Halichondria panicea. Mar Ecol Prog Ser 128: $239-246$

Thompson PA, Levasseur ME, Harrison PJ (1989) Light-limited growth on ammonium vs nitrate: what is the advantage for marine phytoplankton? Limnol Oceanogr 34(6): $1014-1024$

Vismann B (1990) Field measurements of filtration and respiration rates in Mytilus edulis $\mathrm{L}$. An assessment of methods Sarsia 75:213-216

Warner GF, Woodley JD (1975). Suspension feeding in the brittle-star Ophiothrix fragilis. J Mar Biol Ass UK 55:199-210

Watson JE (1992) The hydroid community of Amphibolis seagrasses in southeastern and southwestern Australia. Sci Mar 56:217-227

Wells FE (1978) A quantitative examination of the benthic molluscs of Cockburn Sound, Western Australia. Western Australian Museum, Perth

Wells FE, Threlfall TJ (1980) A survey of the softbottom molluscs of Cockburn Sound, Western Australia. Veliger 23 $131-140$

Wells FE, Walker DI, Hutchings PA (1991) Seagrass, sediment and infauna - a comparison of Posidonia australis, Posidonia sinuosa, and Amphibolis antarctica. III. Consequences of seagrass loss. In: Wells FE, Walker DI, Kirkman $\mathrm{H}$, Lethbridge $\mathrm{R}$ (eds) The marine flora and fauna of Albany, Vol 2. Proc 3rd Int Mar Biol Workshop. Western Australian Museum, Perth, p 635-640

Widdows J, Bayne BL (1971) Temperature acclimation of Mytilus edulis with reference to its energy budget. J Mar Biol Ass UK 51:827-843

Wilson BR, Kendrick GW, Brearley A (1978) The benthic flora of Cockburn Sound, Western Australia. Part 1 Prosobranch gastropods and bivalve molluscs. Report to the Department of Conservation and Environment by the Western Australian Museum, Perth

Wilson RS, Cohen BF, Poore GCB (1993) The role of suspension-feeding and deposit-feeding benthic macroinvertebrates I.n nutrient cycling in Port Phillip Bay. Technical Report No. 10. CSIRO Institute of Natural Resources and Environment, Port Phillip Bay Environment Study, Melbourne

Winter JE (1969) On the influence of food concentration and other factors on filtration fates and food utilization in the mussels Arctica islandica and Modiolus modiolus. Mar Biol 4:87-135

Winter JE (1973) The filtration rate of Mytilus edulis and its dependence on algal concentration, measured by a continuous automatic recording apparatus. Mar Biol 22:317-328

Winter JE (1978) A review on the knowledge of suspensionfeeding in. lamellibranchiate bivalves, with special reference to artificial aquaculture systems. Aquaculture 13:1-33

Manuscript first received: January 23, 1996

Revised version accepted: August 16, 1996 